\title{
Do texto pelas mãos do escritor ao texto nas mãos do leitor: pensando a leitura e a escrita na biblioteca
}

\author{
Alessandra Sexto Bernardes
}

Universidade Federal de Juiz de Fora, Mestrado em Educação

\section{Introduzindo o tema: imagens de leituras e leitores na biblioteca}

Pensar na leitura e na escrita enquanto atos que se efetivam e se constroem num espaço comumente "consagrado" à prática de leitura, como o é o da biblioteca, impele-me a resgatar, na memória, algumas imagens. Imagens de leituras e de leitores. Encontro-as, porém, nas memórias de minhas próprias leituras, e convido o meu leitor, neste momento, a percorrer, comigo, os caminhos traçados por um certo "viajante".

Em busca de um romance interrompido, um viajante-leitor, após ter dado a volta ao mundo, de um livro a outro, encontra no espaço de uma biblioteca, um ponto de paragem para sua agitada navegação. Na esperança acolhedora de encontrar a obra que há tanto procurava, depara-se, no interior de um grande salão, com vários leitores em diálogo - não com menos espanto que possamos agora imaginar, por sabermos se tratar, geralmente, o contexto da biblioteca, de um local cuidadosamente reservado à prática do silêncio - e passa a observá-los. Sentando-se à mesa em que se encontram - enquanto aguarda o bibliotecário que ordena os livros nas estantes, na tentativa de localizar a referência por ele encontrada no ficheiro - escuta um deles dizer:

- Não se admire de me ver sempre a vaguear com os olhos. Com efeito esta é a minha maneira de ler, e só assim a leitura se torna frutuosa para mim. Se um livro me interessa verdadeiramente, não consigo segui-lo para além de algumas linhas sem que a minha mente, captado um pensamento que o texto lhe propõe, ou um sentimento, ou uma interrogação, ou uma imagem, não saia pela tangente e salte de pensamento em pensamento, de imagem em imagem, num itinerário de raciocínios e fantasias que sente necessidade de percorrer até ao fundo, afastando-me do livro até perdê-lo de vista. O estímulo da leitura torna-se-me indispensável, e de uma leitura substanciosa, mesmo que de cada livro não consiga ler mais do que umas quantas páginas. Mas já estas poucas páginas encerram para mim o universo inteiro, a que não consigo pôr termo.

Antes porém que ele falasse tudo aquilo que pensava a respeito do que era também para ele o ato de 
ler, surpreende-se com a intervenção de um outro leitor que ergue das páginas do seu volume "um rosto de cera e uns olhos avermelhados":

- Compreendo-o bem, a leitura é uma operação descontínua e fragmentária. Ou melhor: o objetivo da leitura é uma matéria puntiforme e poeirenta. Na inundante vastidão da escrita, a atenção do leitor distingue segmentos mínimos, aproximações de palavras, metáforas, nexos sintáticos, passagens lógicas, particularidades lexicais que revelam uma densidade de significados extremamente concentrada. São como as partículas elementares que formam o núcleo da obra, à roda da qual roda todo o resto. Ou como o fundo de um vórtice, que aspira e engole as correntes. É através destas espirais que, em relâmpagos que mal se percebem, se manifesta a verdade que o livro pode trazer consigo, a sua substância última. Mitos e mistérios consistem em grãozinhos impalpáveis como o pólen que fica nas patas das borboletas: só quem compreendeu isto pode esperar revelações e iluminações. Por isso a minha atenção, ao contrário do que dizia, senhor, não pode separar-se das linhas escritas nem por um instante. Não devo distrair-me se não quero descurar nenhum indício precioso. Sempre que embato num destes grumos de significado tenho de continuar a escavar à volta para ver se a pepita se transforma em filão. Por isso a minha leitura nunca tem fim: leio e releio procurando todas as vezes a verificação de uma nova descoberta entre as dobras das frases.

Assentindo com as palavras desse leitor - que lhe soam quase familiares - e realizando um pequeno movimento com a cabeça, no intuito de bisbilhotar o que ele está lendo, escuta a opinião de um terceiro leitor:

- Eu também sinto necessidade de reler os livros que já li, mas em cada releitura parece-me ler pela primeira vez um livro novo. Serei eu que continuo a mudar e vejo as coisas novas de que antes não me tinha percebido? Ou a leitura é uma construção que toma forma pondo em conjunto em grande número de variáveis e não se pode repetir duas vezes segundo o mesmo desenho? Todas as vezes que procuro reviver a emoção de uma leitura anterior, obtenho impressões diferentes e inesperadas, e não reencontro as anteriores. Em certas ocasiões parece-me que entre uma leitura e outra existe um progresso: no sentido, por exemplo, de penetrar mais no espírito do texto, ou de aumentar a distanciação crítica. Noutras ocasiões pelo contrário parece-me conservar a recordação das leituras dum mesmo livro uma junto da outra, entusiastas ou frias ou hostis, esparsas no tempo sem uma perspectiva, sem um fio que as ligue. A conclusão a que cheguei é de que a leitura é uma operação sem objeto; ou de que o seu verdadeiro objeto é ela mesma. O livro é um suporte acessório ou mesmo um pretexto.

Antes mesmo de girar o seu pescoço para o lado contrário numa outra tentativa frustrada de ler o título daquele livro aparentemente misterioso, intervém um quarto leitor:

- Se quiserem insistir na subjetividade posso estar de acordo com vocês, mas não no sentido centrífugo que lhes atribuís. Cada novo livro que leio passa a fazer parte desse livro geral e unitário que é a soma das minhas leituras. Isso não acontece com facilidade: para compor esse livro geral, todo o livro particular deve transformar-se, entrar em relação com os livros que li anteriormente, tornar-se o seu corolário, o seu desenvolvimento, a sua confutação, a sua glosa ou o seu texto de referência. Freqüento essa biblioteca há anos e exploro-a volume por volume, estante por estante, mas poderei demonstrar-vos que não fiz mais do que prosseguir a leitura de um único livro.

Num sobressalto, aparece por detrás de uma pilha de volumes encadernados um quinto e, curioso, o viajante o escuta atentamente:

- Também para mim todos os livros que leio levam a um único livro, mas é um livro para lá do tempo, que mal aflora nas minhas recordações. Há uma história que para mim vem antes de todas as outras histórias e de que todas as histórias que leio parecem conter um eco que logo se perde. Nas minhas leituras mais não faço que procurar esse livro lido na minha infância, mas o que dele me lembro é demasiado pouco para o reencontrar. 
Um sexto leitor que passava as estantes, dele se aproxima dizendo qual é para ele o momento mais profícuo de seu ato de leitura:

\footnotetext{
- O momento que para mim mais conta é o que prece-

de a leitura. Às vezes é o título que basta para acender em mim o desejo de um livro que talvez não exista. Às vezes é o incipit do livro, as primeiras frases... Em suma: se para vocês não é preciso muito para pôr a imaginação em movimento, a mim chega-me ainda menos: a promessa da leitura.
}

Sentindo-se atordoado em meio a tantas falas e quase esquecendo-se do livro que procurava, percebe numa outra voz um último comentário, enfim:

- Para mim, pelo contrário, é o fim que conta, mas o fim verdadeiro, último, escondido no escuro, o ponto de chegada a que o livro quer levar. Também eu ao ler procuro espirais - diz acenando ao homem dos olhos avermelhados, -, mas o meu olhar escava por entre as palavras para procurar descortinar o que se recorta ao longe, nos espaços que se estendem para lá da palavra "fim".

Em meio a tantas histórias de leituras e de leitores, passa, então, o viajante, a narrar a sua busca incessante pelos romances que nunca lera até o fim e descobre que elas, também naquele espaço, não se encontram e segue, dali, seu itinerário não se sabe até hoje para onde...

Quais os propósitos de ter encaminhado você, leitor, nas primeiras páginas deste texto, nessa viagem de leitura? Na realidade, trata-se de um episódio narrado por Italo Calvino, em seu belo livro Se numa noite de inverno um viajante [198-], o qual apresenta-se aqui, certamente, um tanto acrescido por palavras que permiti-me escrever, no intuito tão somente de iniciar a discussão que pretendo empreender sobre os atos de leitura e de escrita na biblioteca. E a mim nada pareceu melhor do que começar pelas palavras de leitores - e, se leitores, certamente também escritores - que mesmo virtuais, advindos das páginas de uma obra literária, falam-nos sobre como lêem e sobre o que esperam encontrar nos textos que se pro- põem a ler. Percebemos, claramente, nas palavras de Calvino, os diversos modos de leitura que diferentes leitores efetivam, como também as diferentes leituras que os mesmos leitores realizam em momentos diversos de suas vidas.

O que significa ler e escrever numa biblioteca? Como se constitui o sujeito leitor-escritor? Quais processos entram em jogo quando se está lendo? E escrevendo? Em que instâncias institui-se o leitor no texto escrito? Não são para essas questões novas que procuro respostas definitivas. No conjunto dos discursos já mencionados sobre a leitura/escrita, retomo a voz de Bakhtin que, ao oferecer-lhes uma outra entonação, permite-nos pensar essas práticas também de um outro modo, particular, possibilitando-nos conceber o espaço da biblioteca não só como uma instância cultural, territorializada, mas fundamentalmente como um espaço discursivo no qual se confrontam as mais diversas vozes. Nesse sentido, focalizando a biblioteca em sua dimensão textual-discursiva, busco, neste texto, com base nos pressupostos da teoria enunciativa da linguagem desse autor, erigir uma concepção dos atos de ler e escrever em seus processos de construção no texto, assim como em suas formas de efetivação enquanto práticas socioculturais nas diversas esferas da atividade humana.

Concordando com Geraldi (2001), pensar a leitura e a escrita no interior da perspectiva bakhtiniana implica o enfrentamento de um problema que, segundo ele, reside em

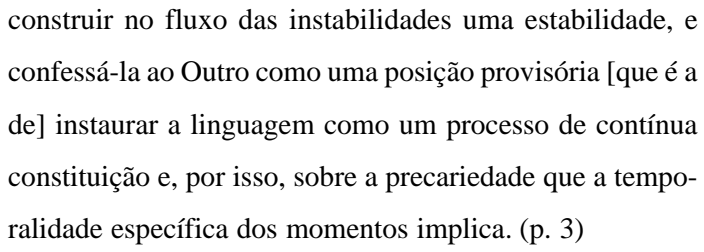

Desse modo, assumo o risco e, num primeiro passo, procurarei traçar o que é, para Bakhtin, a linguagem.

\section{0 que é a linguagem?}

Tendo na linguagem a centralidade de sua obra, Bakhtin buscou em seus estudos ultrapassar as gran- 
des correntes da lingüística de sua época, cujas definições de linguagem, a seu ver, não escapavam de um dualismo (in)fundante, colocando em oposição ora língua/fala, código/mensagem, ora língua/discurso.

No intuito de demonstrar a natureza real da linguagem enquanto fenômeno socioideológico, Bakhtin (1999 [1929]) teceu uma crítica epistemológica radical ao objetivismo abstrato e ao subjetivismo idealista. Reduzindo a língua a um sistema abstrato de formas ou vendo-a como uma expressão da realidade interna, para ele ambas as correntes não atingiam o verdadeiro núcleo da realidade lingüística: a interação verbal.

Enfatizando, assim, a linguagem enquanto processo, Bakhtin elege a enunciação como o motor essencial da língua, pois esta se constitui, segundo ele, numa evolução ininterrupta, ou seja, num processo de criação contínua que se efetiva na e pela interação verbal dos interlocutores. Em outras palavras, a linguagem é uma atividade, um processo criativo, que se materializa pelas enunciações. A realidade essencial da linguagem é, assim, o seu caráter dialógico, não podendo ser compreendida separadamente do fluxo da comunicação verbal:

A verdadeira substância da língua não é constituída por um sistema abstrato de formas lingüísticas nem pela enunciação monológica isolada, nem pelo ato psicológico de sua produção, mas pelo fenômeno da interação verbal, realizada através da enunciação ou das enunciações; a interação verbal constitui assim a realidade fundamental da língua. (idem, p. 123)

Toda enunciação é, portanto, diálogo, ou seja, não há enunciado isolado. Para Bakhtin, qualquer enunciado - oral ou escrito - faz parte de um processo de comunicação ininterrupto, pressupondo, além da presença concomitante de um ser falante e de um ser ouvinte, aqueles enunciados que o antecederam e todos os que o sucederão. Caracteriza-se o enunciado, então, como um elo de uma grande cadeia dialógica que só pode ser compreendido no interior dessa cadeia. Toda palavra, nesse sentido, já é uma contrapalavra, demandando do interlocutor uma resposta, no interior de um processo de compreensão ativo.

Ao refletirmos sobre as práticas de leitura e escrita na biblioteca, não podemos partir do pressuposto, então, de que existe uma língua pronta e acabada, um discurso imutável representado pelos cânones literários "embalsamados" nas estantes e/ou prateleiras. No mesmo sentido, não podemos conceber um processo ensino-aprendizagem que toma essa mesma língua como objeto de ensino previamente definido sobre o qual se debruçariam o aluno e o professor. Ler e escrever na ou a partir da biblioteca compele o sujeito a construir sobre o mundo que o cerca uma representação, oferecendo-a e contrapondo-a à representação de um "outro".

Para Bakhtin, pois, a linguagem é uma atividade sociossemiótica, na qual o movimento da leitura e da escrita pressupõe a consciência prática de um sujeito que funda uma nova relação consigo mesmo, com o "outro" e com o mundo. A palavra é ideológica por natureza e se concretiza como signo ideológico no fluxo da interação verbal, transformando-se e adquirindo diferentes sentidos e significados de acordo com o contexto em que emerge. Ir ao encontro de uma concepção bakhtiniana de linguagem implica, por todas essas considerações, investir na singularidade do acontecimento, compreendendo, assim, que a atividade da linguagem é constitutiva da própria linguagem, das línguas e dos sujeitos. Trata-se, segundo Faraco (1997), de centrar o olhar nas práticas discursivas, ou seja, na língua em sua integridade concreta e viva, percebendo-a não como algo unitário, mas focando a atenção na realidade lingüística que, segundo os pressupostos bakhtinianos, é sempre heteroglótica - plurilíngue, pluridiscursiva, pluriestilística - e imersa numa intrincada rede de relações dialógicas.

\section{0 sujeito da linguagem}

A perspectiva bakhtiniana de linguagem instaura, ao eleger o acontecimento enunciativo como o lugar efetivo de produção da língua, uma outra concep- 
ção de sujeito, ultrapassando a tendência da epistemologia clássica, positivista, que o concebe como um indivíduo detentor de certezas, racional por natureza, marcado pela preocupação da transparência e da unidade, capaz tão-somente de representar o mundo pela linguagem. Ora, por tudo o que foi dito no item anterior, podemos perceber que, ao propor uma versão polifônica e dialógica da enunciação, Bakhtin contesta radicalmente a visão de sujeito como um ente uno, elegendo a linguagem como o lugar privilegiado da construção/constituição da subjetividade.

Geraldi (1995) nos alerta para o fato de que devemos sempre nos indagar sobre o que admitimos quando nos remetemos à idéia de que o sujeito se constitui na e pela linguagem. Segundo ele, o fato de "admitir a noção de constitutividade é colocar em suspeição a esperança que inspira a construção deste horizonte ponto de chegada" (p. 8). Isso porque a própria noção de constitutividade da linguagem e do sujeito implica, segundo as suas considerações, em três outros princípios: o da inconclusibilidade; o da insolubilidade e o do "caráter não-fechado dos "instrumentos' com que opera o processo de constituição" (idem, ibidem).

O sujeito constitui-se, portanto, nos processos interativos dos quais participa, abrindo o espaço para as relações intersubjetivas e para o reconhecimento recíproco da construção ideológica das consciências. Somos tecidos numa rede de relações onde se entrelaçam e entrechocam as várias vozes sociais de uma dada época. Fazemo-nos uns aos outros num fluxo ininterrupto, no movimento, num território sem espaço definido, na passagem. Nosso mundo interior é também uma "arena povoada de vozes sociais em permanente movimento" (Faraco, 1997, p. 11) e, portanto, em nossa incompletude não podemos garantir um terreno estável para nossa constituição.

A linguagem, enquanto processo de constituição da subjetividade, marca as trajetórias individuais de sujeitos que se fazem sociais também pela língua que compartilham. A exploração das contrapalavras das diferentes compreensões é o que permite o cálculo de possibilidade e a construção de novos lugares desterritorializados, a partir dos quais podem ser mobilizados desejos e ações que, respeitando as diferenças, não as transformam em desigualdades.

Superando a visão racionalista do "inescapável método de pensar as partes para nos aproximarmos de respostas provisórias" (p. 3), Geraldi (1999) propõe um movimento talvez inverso, ou melhor, descontínuo, de conceber o pensar a vida em constante porvir. Não tem a vida um autor, mas, sim, sujeitos que se constituem mutuamente e continuamente na linguagem e que são, por natureza, inconclusos. Essa dimensão constitutiva do homem que engloba em si um enquadramento relacional de duas consciências no acontecimento da linguagem é o que torna possível, segundo o autor, um movimento impossível de completude, materializado pelo conceito bakhtiniano de "excedente de visão": "a visão do outro nos vê como um todo com um fundo que não dominamos" (idem, p. 5). Toda experiência em relação a mim, vivida pelo outro, me é inacessível. E é por isso que no encontro/desencontro com o outro, na tensão, nos constituímos enquanto sujeitos na e pela linguagem, que, assim, manifesta-se como mediação sígnica necessária.

A atividade atualiza a língua em diferentes contextos de produção e recepção, os quais trazem consigo as precariedades do singular, do irrepetível, do insolúvel - na situação própria da interlocução - demonstrando, segundo Geraldi (1999), sua vocação estrutural para a transformação, para a mudança. O sujeito constitui-se, assim, no fluxo do movimento território: "lugar de passagem e na passagem a interação do homem com os outros homens no desafio de construir compreensões do mundo vivido" (p. 7). Não há, pois, para a perspectiva bakhtiniana, um terreno estável de constituição, um sujeito pronto e acabado que se apropria, durante a efetivação dos seus atos de leitura e escrita, de uma língua também pronta e acabada. Ler e escrever consistem, nesse sentido, em espaços ampliados de formação e constituição que se dão em tempos e modos diversos.

Que papel reservar ao mundo da escrita, no contexto da biblioteca, nesse processo alteritário de cons- 
tituição? Enquanto formas de interação entre os homens, as práticas do ler e do escrever levam-nos necessariamente a conceber "na história de cada palavra escrita, a história das compreensões do passado e a construção das compreensões do presente" (Geraldi, 1995, p.10). É na palavra que passado, presente e futuro se entrecruzam. $\mathrm{O}$ espaço da biblioteca, carregado das experiências da humanidade, ao se atualizar no movimento da leitura e da escrita, torna-se, assim como a própria linguagem, um lugar vivo e inquietante. "de um longo e secular sussurro, de um diálogo imperceptível entre pergaminho e pergaminho, uma coisa viva, um receptáculo de forças não domáveis por uma mente humana, tesouro de segredos emanados de muitas mentes e sobrevividos à morte daqueles que os produziram" (Eco, 1986, p. 330).

A biblioteca, como lugar de passagem, e como tal, desterritorializado pela atividade leitora/escritora do sujeito que, ao analisar o presente vivido no interior dos limites e das condições das leituras acaba por oferecer-lhes suas contrapalavras criando pelo presente o seu próprio futuro.

\section{Do texto pelas mãos do escritor: a arte da escrita}

Refletindo sobre a origem da linguagem, Bakhtin (1993 [1929]) nos faz vivenciar toda a realidade do ato material do escritor: os tormentos da escrita. Com quais palavras irei produzir um texto? Como as irei eleger? Como colocá-las numa ordem tal que seja possível redigi-las de forma inteligível? Para Bakhtin, essas são perguntas que se relacionam com a linguagem em si e com a natureza da composição de uma obra que tem como material característico e particular o verbal.

Material verbal feito de palavras: o que são, portanto, as palavras? Para Bakhtin, o que difere o material verbal dos demais - como, por exemplo, a argila, o mármore - é exatamente a sua inflexibilidade. Ora, a palavra está inserida num mundo permeado por leis lingüísticas que determinam a ação do escritor - o ato de escrever - no sentido de que tem de dispor das partes para alcançar o todo. Toda palavra denota um significado, uma ação, um acontecimento, uma experiência psíquica que, embora calcados na singularidade, dependem do coletivo para existir na própria coletividade.

Para tornar meu discurso compreensível para um outro, tenho que dispor de todas as leis que regem a organização do material verbal. Essas leis, no entanto, são construídas no próprio tecido social. Mas, ao escrever um texto, tenho que tê-las de antemão para que meu discurso alcance o outro. Dessa maneira, antes de chegar às mãos do leitor, o texto já passou por uma série de transformações que envolvem o processo de criação, pelo autor/escritor, de sua obra: passagem da linguagem interior para enunciação externa; transformação em produto ideológico - a obra em si; adaptação às condições técnicas exteriores. Considerando-se que esse processo envolve, em sua essência, a participação ativa de um ouvinte/leitor potencial e/ou virtual, a atividade da leitura passa a ser, então, uma atividade de co-enunciação, no sentido de que aquele que escreve antecipa, na própria geração de seu texto, os movimentos daquele que, um dia, irá tê-lo em suas mãos.

Bakhtin nos dá suporte para conceber a atividade de leitura/escrita como uma empreitada essencialmente dialógica, ao propor um estudo das produções artísticas e/ou literárias que ultrapassam o estudo da forma pela forma, explicitando, no Discurso na vida e discurso na arte (199_), ${ }^{1}$ as especificidades da comunicação estética, para ele tão social e ideológica quanto o discurso no mundo ético, da vida cotidiana. Bakhtin quer nos mostrar, em suas reflexões, que a obra de arte e/ou o texto literário são produtos da atividade e criatividade humanas sendo, portanto, ideológicos em sua natureza, afetando o contexto extra-artístico, mas, ao mesmo tempo, sendo afetado por ele.

No intuito de construir um espaço conceitual para o modelo da poética sociológica a que se propõe,

${ }^{1}$ In: Freudanism: a marxist critique. New York: Academic Press, 1976. 
Bakhtin rejeita dois pontos de vista que, de acordo com seus pressupostos, são altamente falaciosos: o do método formal e o do método subjetivista. $\mathrm{O}$ primeiro ponto de vista - o do formalismo - compreende a obra de arte/o texto apenas na sua forma material, concebendo-a(o) como artefato cultural, considerando, pois, apenas a estrutura da obra em si, de um ponto de vista lingüístico abstrato no qual o material se funde de forma direta ao meio extra-artístico. Já o segundo - numa perspectiva altamente subjetivista - compreende e estuda apenas a psique individual do criador ou do contemplador de uma obra de arte, muitas vezes chegando a igualar essas duas figuras, centrando-se, assim, nas experiências de um indivíduo no momento da contemplação ou da criação do texto/da obra. Para Bakhtin, ambos pecam no sentido de provocarem o divórcio da parte em relação ao todo, buscando compreender nela, o todo. O objetivo da poética sociológica seria justamente o de romper com esse dualismo, com essas duas posições por ele consideradas extremistas, que reduzem a obra de arte a uma polaridade insustentável.

Bakhtin (199_) considera que a comunicação estética é um fenômeno que engloba três elementos fundamentais, a saber: a obra de arte/o texto, o criador e o contemplador. Esses elementos estão intrinsecamente inter-relacionados, dependendo diretamente um do outro para existir, ou seja, estão em constante relação. Assim, o objeto da poética sociológica reside justamente na busca pela compreensão da natureza dessa forma de comunicação, que se efetiva no seio dessa tríade extremamente complexa. Se não, vejamos as suas próprias palavras nesse sentido:

O que caracteriza a comunicação estética é o fato de que ela é totalmente absorvida na criação de uma obra de arte, e nas suas contínuas recriações por meio da co-criação dos contempladores, e não requer nenhum outro tipo de objetivação. Mas, desnecessário dizer, esta forma única de comunicação não existe isoladamente; ela participa do fluxo unitário da vida social, ela reflete a base econômica comum, e ela se envolve em interação e troca com outras formas de comunicação. (p. 5)
O enunciado poético apresenta-se, desse modo, como uma forma da comunicação estética verbalmente implementada. É nesse ponto que Bakhtin sugere uma outra reflexão, transferindo-se para outra esfera discursiva: a esfera comunicacional cotidiana. Segundo ele, é preciso, antes de se alcançar o entendimento do enunciado poético, procurar analisar com detalhes certos aspectos das falas cotidianas em cujas potencialidades se engendra a própria forma artística. Dito isso, parte do princípio de que, na vida, o discurso verbal não é auto-suficiente, porque emergente de uma situação extraverbal e pragmática com a qual mantém a mais estreita relação. Tudo o que se fala, num processo conjunto, portanto, de interlocução, depende diretamente de fatores extraverbais ao enunciado, ou seja, refere-se ao horizonte espacial e ideacional dos sujeitos envolvidos na situação. Os falantes dotam-se, desse modo, de seus pressupostos e oferecem aos enunciados que constroem uma expressão ideológica calcada em suas posições de classe, inserindose numa situação de comunicação em que tudo é conjuntamente conhecido e unanimamente avaliado. Daí, os conceitos de entoação e apoio coral assumem um papel fundamental nesse tipo de comunicação.

O que diferencia o discurso cotidiano do discurso da obra de arte/do texto não reside, portanto, em seu vocabulário e/ou padrão sintático, mas está na sua relativa dependência do contexto circundante imediato. Declarações avaliativas como, por exemplo, "isto é verdade" ou "isto é mentira" estão carregadas de uma entonação ética, cognitiva e política, ou seja, extrapolam seu conteúdo meramente verbal. Qualquer entoação está no limite do contexto verbal e extraverbal e é ela quem traz para a corrente da vida o enunciado, sendo, nesse sentido, social por excelência.

É com base no jogo da entoação entre os interlocutores - o contemplador e o criador - que Bakhtin traz outro elemento, inserindo-o em um enquadramento relacional que se pensava completo. Um simples e pequeno traço de uma entoação, por exemplo, uma indignação para com determinado assunto, tem de dirigir-se para algum lugar. E, nesse lugar, está justamente o terceiro participante da comunicação, seja 
estética ou calcada na fala cotidiana: o herói. A entonação possui, nesse sentido, uma orientação social dupla. O discurso verbal ou o texto escrito consistem, assim, num evento social; não se auto-encerram no sentido de alguma quantidade lingüística abstrata e nem são derivados psicologicamente da consciência subjetiva do falante tomada em isolamento. A forma e o significado da enunciação dependem da forma e do caráter de interação entre os participantes do evento discursivo.

Como compreender a relação desses elementos no interior de um texto literário? Sabemos que o discurso na arte não é e nem pode ser tão estreitamente dependente de todos os fatores do contexto extraverbal, de tudo aquilo que é conjuntamente visto e avaliado na vida. Tem o autor/escritor de lançar mão do material verbal para fazer a mais ligeira alusão aos eventos do meio extraverbal em seu texto. Assim, afirma Bakhtin que muito mais é exigido do discurso na literatura, pois muito do que poderia permanecer fora do enunciado na vida precisa, na comunicação estética, encontra representação verbal.

Nesse sentido, podemos, mais uma vez, reafirmar a atividade de leitura como interlocução que se faz a partir de uma interlocução já antes iniciada pelo autor/escritor, já que "toda obra poética está estreitamente enredada no contexto não articulado da vida" (Bakhtin, 199_, p. 12). Autor, ouvinte e herói não consistem, nessa perspectiva, em pessoas abstratas que, pela primeira vez, encontram-se no texto poético/literário. Há entre eles um horizonte comum, pois as palavras que compõem qualquer texto emergem do contexto vivo da vida e não são tomadas das páginas de um dicionário. Por isso mesmo, apresentam-se ao leitor repletas de avaliações sociais não articuladas que organizam diretamente a forma de expressão da obra, tanto no momento em que são selecionadas pelo autor/escritor, quando naquele em que este calcula a recepção dessa seleção pelo leitor/ouvinte.

A relação entre autor e herói nunca é, portanto, uma "relação íntima de dois" (idem, p. 16), levando sempre em consideração um outro participante: o ouvinte. O ouvinte possui uma posição especial no even- to discursivo artístico, pois está numa posição bilateral - com respeito ao autor e ao herói - e é essa posição que tem efeito determinado no estilo do enunciado. $\mathrm{O}$ autor, por sua vez, sente o seu ouvinte de diferentes maneiras, podendo estabelecer uma aliança com ele, contra o herói, ou, por outro lado, estabelecer uma relação de profundo desdém e/ou desconfiança, até mesmo alcançando a rudez.

Como elementos constitutivos da própria obra de arte, o valor hierárquico do herói ou evento funcionando como conteúdo do enunciado; o seu grau de proximidade com o autor; e o ouvinte e sua interrelação com o autor, de um lado, e com o herói, de outro, são, pois, os pontos de contato entre as forças sociais da realidade social que a criação artística possui, sendo ela aberta em todos os lados à influência dos outros domínios da vida (ibidem, p. 19).

Todo ato de criação do texto escrito e sua contemplação via leitura englobam, portanto, todos esses fatores em suas relações, que de modo algum prescindem do aspecto técnico da forma, mas, mesmo dependendo diretamente de seus elementos, a eles não se reduzem. Nas palavras de Bakhtin (199_):

A contemplação artística via leitura de uma obra poética começa, certamente, do grafema (imagem visual de palavras escritas ou impressas), mas no instante mesmo desta percepção esta imagem visual dá lugar, e é quase obliterada por outros fatores verbais - articulação, imagem sonora, entoação, significado - que levam por completo para além da fronteira do verbal. [...] Na poética, como na vida, o discurso verbal é um 'cenário' de um evento. [...] O discurso verbal é o esqueleto que só toma forma viva no processo da percepção criativa e, conseqüentemente, só no processo da comunicação social viva. (p. 14)

Passamos, assim, a discutir, no próximo tópico, a arte da leitura, ou seja, a recepção do texto pelo leitor, cuja imagem, vale finalmente ressaltar, nos estudos sobre a poética sociológica de Bakhtin não se confunde com aquela do ouvinte que, a par com o autor e o herói, caracteriza-se como um fator intrínseco, essencial da própria obra em sua estrutura. 


\section{Do texto nas mãos do leitor: a arte da leitura}

E quanto ao verbo ler? Poder-se-á dizer "hoje lê" tal como se diz "hoje chove"? Pensando bem, a leitura é um ato necessariamente individual, muito mais do que o escrever. Admitindo que a escrita consegue superar as limitações do autor, ela apenas continuará a ter sentido quando for lida por uma pessoa singular e atravessar os seus circuitos mentais. Somente o fato de poder ser lido por um indivíduo determinado prova que aquilo que é escrito participa do poder da escrita, um poder baseado em algo que está para além do indivíduo. O universo exprimir-se-á a si mesmo até que alguém possa dizer: "Leio, logo ele escreve". (Calvino, 198_, p. 173).

Mais uma vez, as palavras de Calvino são reveladoras da dimensão da alteridade que envolve os atos de leitura e de escritura. Onde há um leitor, está também ali o ato do escritor. Um texto só adquire pleno sentido, portanto, quando alcança as mãos de um leitor ávido por suas palavras. Sendo assim, leitura e escrita inserem-se no texto enquanto práticas efetivas, engendrando uma relação intersubjetiva entre escritores e leitores, presumindo um quadro comunicacional que prima pela constituição de sentidos.

Até aqui, falamos sobre a criação da obra de arte, digamos, do ponto de vista de sua "interioridade" cujos meandros não excluem, como vimos, as influências recíprocas que exerce e sofre do meio extra-artístico. Interessa-nos, agora, ao tratar da arte da leitura, analisar como os pressupostos bakhtinianos podem nos auxiliar, no sentido de caracterizarmos o ato "exteriorizado" da leitura, ou seja, sobre como o leitor exerce sobre o texto já produzido/escrito, a sua arte.

Relembremos, juntamente com Geraldi (1999), as diferenças entre o mundo da vida e o mundo da arte. Segundo esse autor, para Bakhtin a especificidade do mundo estético está na possibilidade que tem o autor de olhar para o herói como um sujeito acabado, porque produzido na dimensão temporalexistencial da obra enquanto produto cultural. Já no mundo ético, os indivíduos não possuem, enquanto personagens, um autor que lhes coordene os movi- mentos, necessitando, por isso, de outros personagens para existir. O sujeito da linguagem, no mundo da vida, só adquire pleno sentido quando interage com outros sujeitos, elegendo, portanto, como lugar de encontro e de confronto, o terreno instável e precário do evento discursivo.

Para compreendermos como se dá o movimento de estabilidades e instabilidades em cujo bojo se concretiza e/ou se materializa o ato da leitura, o autor nos sugere uma análise dos conceitos bakhtinianos de sentido e de significação:

Se consideramos que uma língua é um conjunto instável de recursos lingüísticos com que construímos representações com 'acentos apreciativos' (portanto, nunca neutros), cada um destes recursos traz em si 'os murmúrios da própria história' condensados com suas significações que se apresentam em cada uma de suas reiterações. E nestas reiterações do 'aqui e agora' da enunciação, estes mesmos recursos se desvestem de suas significações para se revestirem com as vestes que lhe traz o tema específico e único de cada enunciação. (Geraldi, 2001, p. 3)

Introduzir no centro da linguagem a noção de indeterminação de seu suposto sistema é, para o autor, de suma importância, pois, somente desse modo, se poderá extrapolar o sentido comumente atribuído ao ato de leitura como mero reconhecimento de signos, através de um processo mecânico de reconhecimento, ato monológico de descodificação. Ora, enquanto prática sociocultural, ação entre interlocutores, a leitura implica a produção de sentidos, ou seja, prescinde da oferta de contrapalavras que o leitor oferece ao texto, através de um processo que, necessariamente, engloba o reconhecimento, mas que se efetua, primordialmente, via atitude responsiva ativa de dado enunciado no processo de compreensão num contexto específico:

O essencial na tarefa de descodificação não consiste em reconhecer a forma utilizada, mas compreendê-la num contexto concreto preciso, compreender sua significação numa enunciação particular. Em suma, trata-se de perceber 
seu caráter de novidade e não somente sua conformidade à norma. Em outros termos, o receptor, pertencente à mesma comunidade lingüística, também considera a forma lingüística utilizada como um signo variável e flexível, e não como um sinal imutável e sempre idêntico a si mesmo. (Bakhtin, 1999 [1929], p. 93)

Ler é, portanto, descodificar? Sim, mas não somente isso se nessa empreitada o texto permite ao leitor a construção de múltiplos sentidos para as palavras que o compõem. Isso porque, do ponto de vista do trabalho lingüístico, segundo Geraldi (2001), podemos apontar processos de leitura, como, por exemplo, o pragmático, que explora os recursos lingüísticos no intuito de produzir um fechamento de sentidos: o texto como pretexto para o trabalho lingüístico referencial. A exploração desses recursos como meio, porém, de se proliferar outros sentidos, materializase, primordialmente, pelo trabalho lingüístico estético da poesia e da literatura. Entretanto, não é errôneo afirmar que mesmo a leitura que prescinde do trabalho pragmático por parte do leitor produz, ainda que de forma aprisionada, um sentido.

$\mathrm{O}$ ato da leitura não implica, enfim, somente um processo de decifração de códigos estáveis e de construção de sentidos sempre idênticos a si mesmos, mas engloba, fundamentalmente, a constituição de sentidos outros que não são, por sua vez, os mesmos pensados pelo autor da obra. No ato da leitura, portanto, o leitor constitui, e não, como aparentemente pode se chegar a pensar, reconstitui sentidos:

Ler é dar um sentido de conjunto, uma globalização e uma articulação aos sentidos produzidos pelas sequiências. Não é encontrar o sentido desejado pelo autor, o que implicaria que o prazer do texto se originasse na coincidência entre o sentido desejado e o sentido percebido, em um tipo de acordo cultural, como algumas vezes se pretendeu, em uma ótica na qual o positivismo e o elitismo não escaparão a ninguém. Ler é, portanto, constituir, e não reconstituir um sentido. A leitura é uma revelação pontual de uma polissemia do texto literário. (Goulemot, 1996, p. 108)
Se compreendemos, com base nas palavras de Goulemot, o conceito de polissemia proposto por Bakhtin, a operação da leitura só se torna possível no encontro entre a palavra lida e/ou impressa no texto e as contrapalavras do leitor. Mas, como não pode nem o leitor, muito menos o escritor, prever quais as contrapalavras que virão a esse encontro, torna-se impossível, portanto, prever todos os sentidos que a leitura produz. Daí o fato de a leitura não consistir na mera reprodução de sentidos sempre idênticos a si mesmos ou àqueles pensados pelo autor, mas, ao contrário, residir na construção sempre nova e incessante de múltiplos sentidos.

Entretanto, não devemos cair na falsa armadilha de uma concepção romântica da leitura, na qual o texto não seria portador de um sentido particular, proposto por seu autor no momento de sua criação. Ora, vimos no item anterior os vários elementos que se entrecruzam e se entrechocam na comunicação estética. Todo texto possui no momento de sua produção um destinatário, na medida em que este é, considerado pelo autor - situado historicamente - que o produz. Uma concepção ingênua da leitura enquanto produtora de tantos sentidos indefinidos quanto infinitos forem seus leitores e seus contextos, corrompe a tese bakhtiniana de dialogismo. Ler é dialogar com o texto lido. É, portanto, "intertextualizar", trazer para o texto um contexto.

E, nesse sentido, para Brandão (1997), instauramse dois movimentos de leitura no espaço do texto que é, para a autora, marcado pela ambigüidade: um de expansão e outro de filtragem. O primeiro se faz pela proliferação de sentidos permitida pelas lacunas deixadas no texto pelo escritor, enquanto o segundo restringe essa proliferação pelo uso por parte do escritor de estratégias que procuram selecionar, para o leitor, uma interpretação pertinente ao sentido ao qual se propôs desde o momento de geração do texto. Desse modo, segundo a autora, pode-se dizer que, num certo sentido, situa-se o leitor entre a disseminação de sentidos possíveis e as coerções, as restrições inscritas nos textos enquanto artefatos culturais.

É preciso ressaltar, ainda, indo ao encontro dos 
pressupostos bakhtinianos, que a produção/construção dos sentidos no momento da leitura não depende somente do texto em sua materialização verbal. Ora, se concordamos com o conceito de "situação" como "a efetiva realização na vida real de uma das formas, de uma das variedades, do intercâmbio comunicativo social" (Bakhtin, 1993 [1929], p. 247), percebemos que não só o texto traz em si elementos extraverbais que não o afetam somente de fora, sendo também essenciais em sua própria composição -, mas que esses elementos atualizam o próprio leitor, no ato da leitura, e determinam, em parte, os sentidos que aí serão produzidos.

Quem é o leitor que se aventura a ler determinado texto? Qual é a sua história pessoal e a sua história de leitura? Onde o lê? Como o lê? Em companhia de quem e para quem? Os elementos extraverbais que influenciam na inter-relação texto/leitor são denominados por Goulemot (1996) de fora-do-texto. Para o autor, todo leitor é marcado por uma fisiologia, uma história e uma biblioteca: "o sentido, aquele que se constitui por uma leitura historicamente datada, empregado por um indivíduo que tem um destino singular, nasce, portanto, do trabalho que esse "fora-dotexto assim definido opera, para além do sentido das palavras, do agrupamento de frases, sobre o texto" (Goulemot, 1996, p. 108). Toda leitura define, pela própria materialidade do suporte que a engendra, uma atitude do corpo; toda leitura efetiva-se com base no lugar em que se situa e em uma época, ao mesmo tempo em que, enquanto atividade e em um sujeito singular, define-se por aquilo que na leitura constitui a sua marca; enfim, qualquer leitura é uma leitura comparativa, contato de livros com outros livros e da memória do leitor de suas leituras anteriores.

\section{À guisa de conclusão: considerações para se pensar a biblioteca como espaço discursivo}

Para finalizar, retomo Geraldi (2001), assumindo, com ele, que toda experiência de leitura reflete e refrata uma realidade, no sentido em que se consuma como uma "oferta de contrapalavras", no interior de um diálogo entre autor/escritor e ouvinte/leitor, na tecedura permanente de um intertexto, fonte enunciativa de toda linguagem:

Um leitor que não oferece às palavras lidas as suas contrapalavras, recusa a experiência da leitura. É preciso vir carregado de palavras para o diálogo com o texto. E estas palavras que carregamos multiplicam as possibilidades de compreensões do texto (e do mundo) porque são palavras que, sendo nossas, são de outros, e estão dispostas a receber, hospedar e modificar-se face às novas palavras que o texto nos traz. E estas se tornam por sua vez novas contrapalavras, nesse processo contínuo de constituição da singularidade de cada sujeito, pela encarnação da palavra alheia que se torna nossa pelo nosso esquecimento de sua origem. (p. 4)

Pensar a leitura e a escrita na biblioteca implica, portanto, insurgir-se contra os sentidos comumente atribuídos e cristalizados sobre esse espaço de leituras ditas privilegiadas, cujas relações de força que a envolvem - próprias às relações de poder - utilizam o texto para fechá-lo em um único prisma, cristalizando seus múltiplos sentidos possíveis. Pensar a leitura e a escrita na biblioteca implica, em contrapartida, ultrapassar a idéia de que consiste essa instância num edifício, numa sala de leitura, numa mera coleção de livros enfileirados numa estante ou digitalizados nos provedores informáticos. Uma biblioteca, em qualquer esfera da atividade humana, emerge, com base nos pressupostos bakhtinianos, como um espaço discursivo por excelência, o qual só adquire pleno sentido pelo trabalho lingüístico de seus leitores-escritores. E esse trabalho é, segundo Jacob (2000), instaurado por uma dialética criadora entre a totalidade e as partes, entre a promessa de uma memória universal e os itinerários desenvolvidos por cada leitor:

Percurso no interior de um livro, em seguida de livros para livros e dos livros para o mundo, com suas travessias áridas, suas erranças labirínticas e seus momentos de jubilação intelectual, suas caminhadas míopes e seus grandes panoramas. É também uma viagem no tempo, uma ‘anábasis’ nas ramificações da memória do saber e a cria- 
ção de um espaço de encontros utópicos e ucrônicos - convergência das idéias, perenidade e metamorfoses dos modelos e das lições, afinidades eletivas ou escolhas longamente refletidas, em que se reaviva o pensamento e o saber de outrem e de outrora através do comentário, da leitura e do jogo livre das digressões. (p. 10)

Pensar a leitura e a escrita na biblioteca implica, desse modo, em associar à arqueologia de seus conceitos e do imaginário social uma socioistória de suas práticas de leitura e escrita que evidencie essa instância discursiva como o reflexo e a refração de condições sociais, culturais, educacionais e econômicas de uma dada época. Quais são os seus leitores? Por que e como se lê/escreve numa biblioteca? Qual é a situação, a finalidade e o processo de uma atividade intelectual que pressupõe o recurso aos livros? Como, do papiro à tela do computador, a própria materialidade dos textos, as condições de sua produção/reprodução e de seu acesso produzem formas de apropriação, andamento e interpretação específicos? Implica, enfim, em acreditar, como o leitor-viajante de Calvino, que não existe um verdadeiro e único sentido de um texto, pois que cada leitura é sempre reescrita, sempre reencontro com um texto interrompido pelas contrapalavras de outras leituras e leitores.

ALESSANDRA SEXTO BERNARDES é mestranda do Programa de Pós-Graduação em Educação da Universidade Federal de Juiz de Fora. Publicou Bibliotecas e livrarias no discurso de crianças e adolescentes (com Paula M. Teixeira. In: FREITAS, Maria Teresa de Assunção e COSTA, Sérgio Roberto (orgs.). Leitura e escrita na formação de professores. São Paulo: Musa e Juiz de Fora: Ed. UFJF, 2002); O papel da biblioteca escolar na formação do sujeito leitor-escritor (Presença Pedagógica, v. 8 nº 47, set./out. 2002). No prelo: A pesquisa escolar em tempos de Internet (Teias, Revista da Faculdade de Educação da UERJ). Participa da pesquisa A construção/produção da escrita na Internet e na escola: uma abordagem sociocultural (continidade e desdobramentos), em realização no Grupo de Pesquisa Linguagem, Interação e Conhecimento, coordenado pela professora doutora Maria Teresa de Assunção Freitas, do Núcleo de Pesquisa e Estudos em Linguagem, do mesmo Programa.E-mail: asexto@bol.com.br

\section{Referências bibliográficas}

BAKHTIN, Mikhail, (199_). Discurso na vida e discurso na arte (sobre poética sociológica). Tradução de Cristóvão Tezza, para uso didático (mimeo).

, Que és el lenguaje? (1993 [1929]). In: SILVESTRI, Adriana; BLANCK, Guillermo (orgs). Bajtín y Vigotski: la organización semiótica de la consciencia. Barcelona: Anthropos. p. $217-243$.

(1999 [1929]). Marxismo e filosofia da linguagem. São Paulo: Hucitec.

(1992). Estética da criação verbal. São Paulo: Martins Fontes.

BRANDÃO, Helena H. Nagamine, (1997). Escrita, leitura, dialogicidade. In: BRAIT, Beth (org.). Bakhtin, dialogismo e construção de sentido. Campinas: Editora da UNICAMP. p. 281-290.

CALVINO, Ítalo, (198_). Se numa noite de inverno um viajante. $2^{\mathrm{a}}$ ed. Lisboa: Veja.

ECO, Umberto, (1986). O nome da rosa. Rio de Janeiro: Record. FARACO, Carlos Alberto, (1997). Falante: que bicho é esse, afinal? Curitiba (mimeo).

GERALDI, João Wanderley (1995). Convívio paradoxal com o ensino da leitura e escrita. Texto em versão preliminar, escrito para discussão em mesa-redonda do GT Alfabetização, leitura e escrita, na $18^{\mathrm{a}}$ Reunião Anual da ANPEd (mimeo).

, (1999). A linguagem nos processos sociais de constituição da subjetividade. Questões para pensar a cidadania: a língua e o imaginário (mimeo).

, (2001). Leitura: uma oferta de contrapalavras. Conferência proferida no $13^{\circ}$ Congresso de leitura do Brasil. Campinas: Unicamp (mimeo).

GOULEMOT, Jean Marie, (1996). Da leitura como produção de sentidos. In: CHARTIER, Roger (org). Práticas da leitura. São Paulo: Estação Liberdade. p. 107-116.

JACOB, Christian, (2000). Prefácio. In: BARATIN, Marc, JACOB, Christian (orgs). O poder das bibliotecas: a memória dos livros no Ocidente. Rio de Janeiro: Editora da UFRJ, p. 9-20.

Recebido em setembro de 2002

Aprovado em novembro de 2002 